\title{
EFEKTIVITAS BISNIS STARTUP DIGITAL PT. JOJO NOMIC INDONESIA DALAM NILAI KEUNTUNGAN DAN IBADAH ERA COVID-19
}

\author{
Lutfi Nur Agustian \\ Universitas Trisakti \\ luthfinuragustian@gmail.com \\ Roikhan MA \\ UIN Syarif Hidayatullah Jakarta \\ roikhan.ma@uinjkt.ac.id
}

\begin{abstract}
This study aims to analyze the level of effectiveness of the performance of PT. Jojo Nomic Indonesia, a startup (startup company) in the field of technology, with the DEA method and Islamic values which is reflected in the prayer values of its employees during the 2016-2019 period and looks at the effect of input and output variables on the company's growth rate. The case study which is the object of this research is at PT. Jojo Nomic Indonesia. The input variables used are the Accumulation of Number of New and Renewal Customers and Number of Leads (Potential Customers) Entered. While the output variable is Operating Income. Islamic values that are used are the weight of the value of prayer worship taken from the daily assessment of employee worship during the 2016-2019 time span. Its effect on performance effectiveness can be seen using the calculation of the reflexivity value of worship. The results of this study indicate from the data on the effectiveness of employee performance it can be concluded that the increase in the effectiveness of employee performance is in line with the increase in the value weights in worship. This is reflected in the value of worship reflexivity in the performance of employees, which has been increasing from 2016-2019. The peak will occur in 2019, where the effectiveness of performance as seen from the output variable (operating income) reaches a maximum of $100 \%$ in line with an increase which is also quite significant in weighing the value of employee worship to $90 \%$. So that the reflexivity value can be calculated at a percentage of $90 \%$. In other words, the value of prayer worship tends to have a major effect on increasing the effectiveness of employee performance at PT. Jojo Nomic Indonesia.
\end{abstract}

Keywords: Effectiveness, DEA, Digital Startup, Islamic Values

\section{PENDAHULUAN}

Seiring dengan perkembangan zaman, terutama di era baru perekonomian seperti saat ini, banyak perusahaan baru bermunculan. Bermula dari perusahaan rintisan yang berisikan hanya segelintir orang. Dengan segerombol ide yang dimiliki, para pebisnis startup, yang biasanya diisi oleh kaum muda, memulai bisnisnya tanpa perlu banyak perhitungan. Pemanfaatan penuh terhadap perkembangan teknologi sering kali menjadi kunci atas suksesnya perusahaan startup berkembang dalam bisnisnya. Tentu, yang paling diuntungkan di sini, dan memang menjadi tren kebanyakan perusahaan rintisan baru bermunculan, yaitu startup digital atau dalam pengertian sederhana dapat diartikan sebagai sebuah perusahaan rintisan berbasis teknologi.

Dengan semakin banyaknya perusahaan rintisan di bidang teknologi (startup digital) yang bermunculan, maka secara alamiah hal itu akan mendatangkan kompetisi atau persaingan dalam bisnis. Terutama sekali, dalam hal ini, persaingan di industri startup digital umumnya berada pada sektor permodalan atau investasi yaitu tentang seberapa mampu sebuah startup digital mendatangkan investasi untuk menunjang keberlangsungan bisnisnya. Di sisi lain, seperti kata pepatah, "takkan ada asap jika tak ada api", begitu juga habit para investor, mereka tidak akan mau datang jika tidak ada sebab yang memanggil mereka untuk datang. Di antara sebab yang bisa mendatangkan investor untuk menyuntikkan dananya ke startup digital yaitu 
besaran valuasi aset perusahaan tersebut. Maka, untuk menghadapi persaingan tersebut, perlu ada faktor-faktor yang harus diperhatikan, salah satunya dilihat dari pengukuran tingkat efektivitas kinerja perusahaan.

Dalam konsep efektivitas yang merupakan suatu konsep yang bersifat multidimensional, maka makna yang diungkapkan sering berbeda, walaupun pada akhirnya tujuan dari efektivitas itu adalah pencapaian tujuan. Secara etimologi kata efektivitas berasal dari kata efektif, dalam bahasa inggris "effective" telah mengintervensi ke dalam bahasa Indonesia dan memiliki makna "berhasil". Soekanto (1990) menerangkan efektivitas berasal dari kata effektiviens yang berarti ukuran sampai sejauh mana suatu kelompok mencapai tujuan. Beberapa ahli berpendapat tentang efektivitas seperti Miller dalam Tangkilisan (2005) mengungkapkan bahwa:

"Effectiveness be define as the degree to which a social system achieve its goals. Effectiveness must be distinguished from efficiency. Efficiency is meanly concerd with goal attainment. (efektivitas dimaksud sebagai tingkat seberapa jauh suatu system sosial mencapai tujuannya. Efektivitas ini harus dibedakan dengan efisiensi. Efisiensi terutama mengandung pengertian perbandingan antara biaya dan hasil sedangkan efektivitas secara langsung dihubungkan dengan pencapaian suatu tujuan)."

Menurut Bastian dalam Tangkilisan (2005) menyatakan efektivitas adalah hubungan antara output dan tujuan, dimana efektivitas diukur berdasarkan seberapa jauh tingkat output, kebijakan dan prosedur dari organisasi mencapai tujuan yang telah ditetapkan. Artinya bahwa efektivitas dapat dilihat melalui pencapaian hasil yang kemudian disesuaikan dengan tujuan yang telah direncanakan sebelumnya. Sedangkan dalam pendapat lain, efektivitas adalah pengukuran dalam arti tercapainya sasaran atau tujuan yang telah ditentukan sebelumnya.

Selanjutnya, untuk mengidentifikasi adanya efektivitas peningkatan kinerja di startup digital PT. Jojo Nomic Indonesia, perlu adanya penilaian perkembangan kinerja yang dapat dilihat dari dua indikator berikut:

1. Peningkatan Permodalan (Investasi) yaitu data yang didapat dari penghitungan pertumbuhan nilai investasi pada tahun berjalan dibandingkan dengan nilai investasi pada saat pertama kali perusahaan didirikan.

2. Pertumbuhan Valuasi Aset yaitu data yang didapat dari penghitungan pertumbuhan valuasi pada tahun berjalan dibandingkan dengan tahun sebelumnya.

Di bawah ini merupakan data persentase peningkatan permodalan dan pertumbuhan valuasi asset dari tahun 2016 sampai tahun 2019 di PT. Jojo Nomic Indonesia.

Tabel 1. Perkembangan kinerja PT. Jojo Nomic Indonesia (2016-2019)

\begin{tabular}{|c|c|c|c|c|}
\hline & 2016 & 2017 & 2018 & 2019 \\
\hline $\begin{array}{c}\text { Peningkatan } \\
\text { Permodalan } \\
\text { (Investasi) }\end{array}$ & $20 \%$ & $30 \%$ & $35 \%$ & $50 \%$ \\
\hline $\begin{array}{c}\text { Pertumbuhan } \\
\text { Valuasi Aset }\end{array}$ & $2,5 \%$ & $5 \%$ & $20 \%$ & $45 \%$ \\
\hline
\end{tabular}

Sumber: Annual Report PT. Jojo Nomic Indonesia 2019

Dari data di atas dapat dilihat bahwa dari tahun ke tahun terjadi peningkatan permodalan (investasi) yang masuk ke PT. Jojo Nomic Indonesia yaitu meningkat sebesar $20 \%$ pada tahun 2016 dibandingkan dengan tahun 2015 di mana perusahaan pertama kali didirikan. Kemudian, di tahun 2017 dan 2018 juga terjadi peningkatan dengan persentase masing-masing yaitu $30 \%$ dan $35 \%$ dibandingkan dengan tahun 2015. Ini artinya, terjadi pertumbuhan besaran investasi dari tahun 2017 ke 2018 sebesar 5\%. Kemudian, terjadi peningkatan yang cenderung tinggi di tahun 2019 yaitu 50\% dibandingkan tahun 2015 dan meningkat sebesar 15\% dari tahun sebelumnya, sebuah pencapaian yang cukup signifikan untuk sebuah industri startup digital yang baru merintis bisnisnya selama 4 tahun.

Dari sisi pertumbuhan valuasi aset juga terjadi peningkatan yang cukup signifikan dari tahun ke tahun di periode tahun 2016-2019. Dapat dilihat pada data, bahwa di tahun 2016 valuasi aset meningkat sebesar 2,5\% dari tahun 2015, kemudian meningkat terus dari tahun ke tahunnya sampai pada tahun 2019 pertumbuhannya mencapai $45 \%$. Hal ini tentu menjadi sebab dari peningkatan permodalan yang juga terjadi dari tahun ke tahun di PT. Jojo Nomic Indonesia. Dari sisi pertumbuhan valuasi 
asetnya sendiri, tentu ada faktor-faktor yang menyebabkan terjadinya pertumbuhan valuasi aset, salah satu faktor terpentingnya yaitu efektivitas kinerja perusahaan dalam menggunakan sumber dayanya.

Penggunaan sumber-sumber daya bisa dikatakan efisien apabila : (1) Seluruh sumbersumber daya yang tersedia sepenuhnya digunakan; (2) Corak penggunaannya adalah sudah sedemikian rupa sehingga tidak terdapat lagi corak penggunaan lain yang akan memberikan tambahan kemakmuran bagi masyarakat/individu (Sukirno, 2008). Efisiensi di dalam konsep produksi cenderung menilai secara teknis dan operasional, sehingga efisiensi di dalam konsep produksi umumnya dilihat dari sudut pandang teknis dan biaya. Efisiensi dalam konsep produksi terbatas pada melihat hubungan teknis dan operasional dalam suatu proses produksi, yaitu konversi input menjadi output. (Sutawijaya, Adrian dkk, 2009:53).

Kompleksnya permasalahan dalam industri startup digital yang semakin berkembang saat ini, maka perlu adanya alat pengukuran untuk bertahan menghadapi persaingan. Selain fungsi efektivitas yang dapat mengukur nilai kinerja, maka dirasakan perlu adanya penambahan alat analisis dari nilai ibadah selain untuk meningkatkan nilai kerohanian juga mendapatkan manfaat di dunia maupun akhirat. Makna ibadah merupakan proses yang alami dalam setiap aktivitas kehidupan termasuk ekonomi. Sesuai dengan Quran Surat Adz-Dzariyat [51]: 56 yang berbunyi:

Artinya:

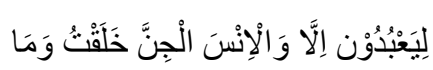

Dan tidak Aku ciptakan jin dan manusia kecuali untuk beribadah.

Pandemi Covid-19 yang sedang mewabah, bukan hanya di Indonesia, tapi juga Dunia, mengubah pola kehidupan masyarakat dunia saat ini. Karena penularannya yang begitu cepat, maka perlu adanya langkah-langkah pencegahan sebagai upaya menghentikan proses penularan tersebut. Di antara langkah yang banyak diambil oleh pemerintahan di seluruh Dunia yaitu melakukan campaign kepada masyarakat agar melakukan social distancing. Beberapa di antaranya juga mengeluarkan dalam bentuk kebijakan seperti regional lockdown, yaitu kebijakan untuk menutup akses wilayah keluar masuk di suatu daerah dan membatasi pergerakan orang-orang yang ada di dalam wilayah daerah tersebut.

Tidak terkecuali di Indonesia, buah dari social distancing campaign itu yakni keluarnya kebijakan Pembatasan Sosial Berskala Besar (PSBB). Garis besar dari kebijakan ini pada intinya untuk melakukan pembatasan pergerakan orang baik di dalam wilayah, apalagi antar wilayah, dengan pemberlakuan yang ketat disertai dengan adanya inspeksi wilayah dan penjagaan. Selain itu, masing-masing daerah yang menerapkan PSBB boleh memberikan sanksi kepada warganya yang melanggar. Dengan demikian, tentu, kebijakan ini berdampak banyak ke berbagai sektor kehidupan masyarakat, terutama ekonomi. Dari sisi dampak ekonomi, tidak dapat disangkal pula, kebijakan ini berdampak ke perusahaan-perusahaan di wilayah tempat di mana kebijakan PSBB tersebut diberlakukan.

PT. Jojo Nomi Indonesia sebagai salah satu perusahaan startup di bidang teknologi yang sehari-harinya menjalankan operasional bisnis di ruang perkantoran, tentu menjadi salah satu dari sekian banyak perusahaan yang ter-dampak kebijakan PSBB wabah Covid-19 ini. Sebagaimana diatur dalam kebijakan PSBB, untuk perusahaan yang menjalankan operasional bisnis sehari-harinya di kantor harus menerapkan pola kerja dari rumah (work from home, selanjutnya disebut wfh) bagi para karyawannya. Peraturan ini muncul dalam rangka menunjang tujuan PSBB yaitu berkurangnya pergerakan dan interaksi sosial secara langsung antar warga masyarakat di suatu wilayah guna memutus rantai penyebaran/penularan virus Covid-19 ini. Oleh karena itu, dalam rangka mematuhi peraturan tersebut sekaligus juga mendukung program pemerintah, PT. Jojo Nomic Indonesia kemudian memberlakukan peraturan wfh bagi seluruh karyawannya. Pemberlakuan kebijakan wfh ini tentunya menjadi dampak pertama yang nyata dirasakan oleh seluruh karyawan di perusahaan.

\section{LANDASAN TEORI}

Penelitian selama ini berbasiskan pola berpikir linier dari pendekatan yang memisahkan keilmuan dengan keagamaan, sehingga otomatis makna ibadah di dalam proses berpikir tersebut tercerabut dengan sendirinya. Sekarang scholar muslim melakukan pendekatan yang genuine dari Islam dengan membenamkan proses alat analisis berupa makna ibadah atau shalat. 
Ibadah merupakan proses yang alami dalam setiap aktivitas hidup manusia termasuk ekonomi. Selama ini ilmu ekonomi selalu mengadopsi teori barat sehingga nilai-nilai keislaman menjadi tersingkirkan, padahal Allah subhanahu wa ta'ala sudah menetapkan dalam Al-Qur'an tentang teori ekonomi yaitu transaksi jual beli pada surat al-baqarah 275:

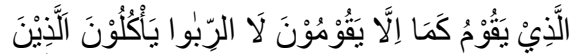

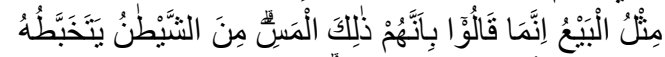

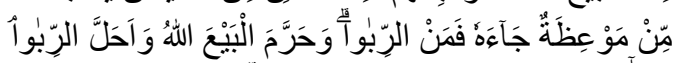

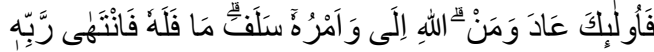

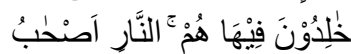

\section{Artinya:}

Orang-orang yang Makan (mengambil) riba tidak dapat berdiri melainkan seperti berdirinya orang yang kemasukan syaitan lantaran (tekanan) penyakit gila. Keadaan mereka yang demikian itu, adalah disebabkan mereka berkata (berpendapat), Sesungguhnya jual beli itu sama dengan riba, Padahal Allah telah menghalalkan jual beli dan mengharamkan riba. Orang-orang yang telah sampai kepadanya larangan dari Tuhannya, lalu terus berhenti (dari mengambil riba), Maka baginya apa yang telah diambilnya dahulu (sebelum datang larangan); dan urusannya (terserah) kepada Allah. Orang yang kembali (mengambil riba), Maka orang itu adalah penghuni-penghuni neraka; mereka kekal di dalamnya.

Konsep dalam alat analisis ekonomi Islam memperoleh apresiasi dari berbagai sudut pandang. Ada yang memulai dari filosofi tauhid, ada yang berangkat dari perspektif mashlahah ada pula yang melihat dari makna ibadah. Dalam teori $\mathrm{H}$ yang merupakan singkatan dari HAHSLM menggunakan sudut pandang makna ibadah. Definisi teori $\mathrm{H}$ dari kata HAHSLM menurut Aziz (2015) adalah :

1. Secara sempit, teori $\mathrm{H}$ diartikan sebagai teori dasar tiga dominan dengan konteks tertentu dalam lima dimensi susunan invariant.

2. Secara luas, penggunaan paling umum teori $\mathrm{H}$ dapat diartikan sebagai teori konsep dasar pola penciptaan dengan hubungan tertentu. $\mathrm{H}$ berasal dari rumus $\mathrm{H}=\mathrm{A} . \mathrm{H}(\mathrm{S}, \mathrm{L}, \mathrm{M}) . \mathrm{Al}$-Qur'an surat Hijr, juga singkatan dari Huda atau Hidup.
Sedangkan makna teori $\mathrm{H}$ antara lain : (Aziz, 2015)

1. Sebuah himpunan utuh atau menyeluruh atau bagian terintegrasi akan terdiri dari 3 (tiga) unsur utama yaitu primer (pencipta), sekunder (ciptaan/penerima) dan tertier (ibadah/pemancar) yang bisa bermuatan positif.

2. Tiga unsur tersebut akan memenuhi pernyataan bahwa sekunder dibawah primer akan melakukan tertier (manusia diciptakan Tuhan untuk beribadah).

Filosofi teori $\mathrm{H}$ dapat di artikan sebagai nilai islam, dengan konsep yang memiliki makna ibadah dan kehidupan.

\section{Pendekatan Covid-19 Dalam Perusahaan}

Sebagai sebuah perusahaan rintisan yang sedang dalam masa produktif (memasuki tahun ke-4 bagi perusahaan startup merupakan tahuntahun produktif yang krusial), tentunya PT. Jojo Nomic Indonesia tidak ingin melewatkan momentum ini, atau sekedar terlena dengan excuse adanya kebijakan atas pandemi Covid-19. Maka, adaptasi terhadap perubahan kondisi menjadi kunci penting untuk membuat momentum produktivitas ini tetap terjaga. Hal ini pula yang kemudian disadari benar oleh pihak manajemen perusahaan dan diimplementasikan melalui pemberlakuan peraturan-peraturan baru yang diterapkan selama masa wfh ini.

Di antara beberapa kebijakan tersebut, misalnya, selama wfh karyawan diwajibkan melakukan pelaporan progres pekerjaan kepada stakeholder terkait sebanyak tiga kali sehari di waktu-waktu yang telah disepakati bersama. Contoh lain, selama wfh karyawan hanya boleh kerja dari rumah, kecuali dalam keadaan sangat darurat yang memaksa karyawan untuk kerja di tempat lain, dan hal ini dapat ter-monitor langsung melalui aplikasi absensi yang digunakan seluruh karyawan. Atau, contoh lain lagi, setiap jam 9 pagi, karyawan wajib hadir dalam sesi morning sharing melalui media conference call. Bagi karyawan yang tidak mematuhi peraturan-peraturan ini selama masa wfh maka akan ada sanksi beragam yang diberikan sebagai bentuk hukuman, mulai dari dipotong jatah cuti sampai pemotongan gaji karyawan. Tidak lain, tujuan dari pemberlakuan semua peraturan ini yaitu untuk tetap menjaga momentum kinerja karyawan dan membuat perusahaan tetap tegap dalam kondisi krisis. Dan, sejauh ini, perusahaan telah membuktikan bahwa 
bisnis yang dijalankan dengan konsep Internet Based Company seperti ini mampu beradaptasi dengan cepat di tengah perubahan kondisi krisis semacam ini.

\section{METODE PENELITIAN}

Penelitian ini meliputi analisis tingkat efektivitas PT. Jojo Nomic Indonesia pada periode tahun 2016-2019 dengan metode Data Envelopment Analysis (DEA) dan nilai islam. Data yang digunakan adalah laporan tahunan dari divisi Business Development (BD) PT. Jojo Nomic Indonesia dengan mengambil dua variable input dan satu variabel output. DEA merupakan sebuah pendekatan non-parametik yang pada dasarnya merupakan teknik berbasis linier programming. DEA bekerja dengan langkah mengidentifikasi unit-unit yang tidak dievaluasi input serta output unit tersebut. Kemudian menghitung nilai produktivitas dan mengidentifikasi unit mana yang tidak menggunakan input secara efisien atau tidak menghasilkan output secara efektif. Produktivitas yang diukur bersifat komparatif karena hanya membandingkan antar unit pengukuran dari 1 set data yang sama (Rosyadi dan Fauzan, 2011).

Tujuan analisis DEA adalah untuk menilai efisiensi dalam penggunaan sumber daya (input) untuk mencapai hasil (output) yang tujuannya untuk maksimalisasi efisiensi. Selain itu, DEA menghitung efisiensi pada sebuah organisasi yang berada dalam kelompok terhadap kinerja organisasi terbaik pada kelompok yang sama. Unit individual yang dianalisa didalam DEA disimbolkan sebagai DMU (Decision Making Unit) atau Unit Pengambilan Keputusan (UPK) (Naufal dan Firdaus, 2017:205).

\section{Jenis dan Objek Penelitian}

Dalam penelitian terdapat dua variable input yaitu "Akumulasi Jumlah Pelanggan Baru dan Renewal" dan "Jumlah Leads (Potential Customer) Masuk". Sedangkan variabel outputnya yaitu Pendapatan Operasional. Priode yang digunakan yaitu tahun 2016-2019. Tahap pertama dalam penelitian ini menggunakan Data Envelopment Analysis (DEA) dan selanjutnya tahap kedua menggunakan pendekatan metodologi dengan nilai ibadah

\section{Metode Pengumpulan Data}

Metode pengumpulan data yang digunakan pada penelitian ini adalah menggunakan data laporan tahunan dari divisi Business
Development (BD) PT. Jojo Nomic Indonesia periode tahun 2016-2019, serta wawancara kepada karyawan-karyawan di PT. Jojo Nomic Indonesia.

\section{Pendekatan Covid-19}

Dalam menjalankan bisnisnya, PT. Jojo Nomic Indonesia menggunakan pola Business to Business (selanjutnya disebut dengan B2B) yakni pola kerja sama antara satu perusahaan dengan perusahaan lainnya. Atau, dengan kata lain, dapat dikatakan bahwa pelanggan (customer) dari PT. Jojo Nomic Indonesia ini merupakan perusahaan/organisasi, bukan perseorangan sebagaimana pola bisnis B2C. Dari informasi tersebut dapat diasumsikan, jika terjadi dampak negatif pada perusahaan-perusahaan lain yang menjadi pelanggan PT. Jojo Nomic Indonesia, maka besar kemungkinan hal tersebut dapat mempengaruhi kerja sama yang terjalin antara perusahaan ter-dampak tersebut dengan PT. Jojo Nomic Indonesia. Dan, fakta di lapangan membuktikan bahwa asumsi tersebut benar terjadi.

Sampai akhir bulan April ini, perusahaan sudah kehilangan beberapa pelanggan penting dengan angka kontrak kerja sama yang besar. Umumnya mereka yang lepas kerja sama adalah perusahaan di sektor industri yang sangat rentan sekali ter-dampak perubahan kondisi krisis akibat wabah ini seperti industri retail, industri jasa pariwisata, industri jasa penerbangan, dan industri event organizer yang pemasukannya menurun drastis sejak pandemi Covid-19 mewabah di Indonesia. Selain kontrak kerja sama yang lepas dari beberapa pelanggan penting di sektor industri terdampak, beberapa proyek juga terpaksa tertunda pelaksanaannya dan hal ini tentu berdampak pula terhadap tertundanya proses pembayaran. Ujungnya, semua permasalahan ini men-distraksi sekaligus mengoreksi target pemasukan perusahaan.

Tentu hal ini tidak baik untuk keseimbangan perusahaan di tengah usahanya untuk terus beradaptasi menjaga ritme produktivitas karyawan. Di sisi lain, menjadi pelajaran penting bagi perusahaan bahwa keseimbangan itu akan terjadi apabila ditopang oleh dua kekuatan secara simultan, yaitu internal dan eksternal. Meskipun dari sisi internal ritme produktivitas karyawan tetap dijaga untuk menjaga keseimbangan, namun hantaman badai dari sisi eksternal juga tidak bisa dipungkiri tetap akan mengganggu keseimbangan itu jika tidak 
segera diatasi dengan langkah-langkah lanjutan yang cepat dan tepat sasaran.

\section{HASIL DAN PEMBAHASAN}

Dalam penelitian ini menggunakan analisis nonparemetik dengan metode Data Envelopment Analysis (DEA). Fungsi DEA yaitu mengukur nilai efisiensi untuk mengidentifikasi adanya peningkatan kinerja. Pada penelitian ini terdapat dua variabel input yaitu "akumulasi jumlah pelanggan baru dan renewal" dan jumlah leads (potential customer). Sedangkan variable outputnya yaitu pendapatan operasional. Data dari ke semua variabel tersebut diambil dari laporan penjualan tahunan divisi Business Development (BD) PT. Jojo Nomic Indonesia pada priode tahun 2016-2019, berikut data laporannya:

Tabel 2. Efektivitas Pencapaian Penjualan

Tahunan PT. Jojo Nomic Indonesia

\begin{tabular}{|c|c|c|c|c|c|}
\hline Tahun & Variable & Actual & Target & To Gain & Achieved \\
\hline \multirow[t]{3}{*}{2019} & $\begin{array}{c}\text { Akumulasi } \\
\text { Jumlah } \\
\text { Pelanggan } \\
\text { Baru dan } \\
\text { Renewal }\end{array}$ & 1008 & 1008 & $0 \%$ & $100 \%$ \\
\hline & $\begin{array}{c}\text { Jumlah Leads } \\
\text { (Potential } \\
\text { Customer) } \\
\text { Masuk } \\
\end{array}$ & 1587 & 1587 & $0 \%$ & $100 \%$ \\
\hline & $\begin{array}{c}\text { Pendapatan } \\
\text { Operasioal }\end{array}$ & 3000 & 3000 & $0 \%$ & $100 \%$ \\
\hline \multirow[t]{3}{*}{2018} & $\begin{array}{l}\text { Akumulasi } \\
\text { Jumlah } \\
\text { Pelanggan } \\
\text { Baru dan } \\
\text { Renewal } \\
\end{array}$ & 90 & 100 & $10 \%$ & $90 \%$ \\
\hline & $\begin{array}{c}\text { Jumlah Leads } \\
\text { (Potential } \\
\text { Customer) } \\
\text { Masuk } \\
\end{array}$ & 250 & 250 & $0 \%$ & $100 \%$ \\
\hline & $\begin{array}{c}\text { Pendapatan } \\
\text { Operasioal } \\
\end{array}$ & 2250 & 2500 & $10 \%$ & $90 \%$ \\
\hline \multirow[t]{3}{*}{2017} & $\begin{array}{l}\text { Akumulasi } \\
\text { Jumlah } \\
\text { Pelanggan } \\
\text { Baru dan } \\
\text { Renewal }\end{array}$ & 72 & 90 & $20 \%$ & $80 \%$ \\
\hline & $\begin{array}{c}\text { Jumlah Leads } \\
\text { (Potential } \\
\text { Customer) } \\
\text { Masuk }\end{array}$ & 220 & 220 & $0 \%$ & $100 \%$ \\
\hline & $\begin{array}{c}\text { Pendapatan } \\
\text { Operasioal }\end{array}$ & 1760 & 2200 & $20 \%$ & $80 \%$ \\
\hline \multirow[t]{3}{*}{2016} & $\begin{array}{c}\text { Akumulasi } \\
\text { Jumlah } \\
\text { Pelanggan } \\
\text { Baru dan } \\
\text { Renewal } \\
\end{array}$ & 52,5 & 75 & $30 \%$ & $70 \%$ \\
\hline & $\begin{array}{c}\text { Jumlah Leads } \\
\text { (Potential } \\
\text { Customer) } \\
\text { Masuk }\end{array}$ & 150 & 150 & $0 \%$ & $100 \%$ \\
\hline & $\begin{array}{l}\text { Pendapatan } \\
\text { Operasioal } \\
\end{array}$ & 1050 & 1500 & $30 \%$ & $70 \%$ \\
\hline
\end{tabular}

Sumber: data diolah menggunakan DEA

Dalam perhitungan di atas, dapat dilihat bahwa efektivitas penjualan software digital pada perusahaan startup PT. Jojo Nomic Indonesia mengalami peningkatan dari tahun ke tahun untuk variabel input akumulasi jumlah pelanggan baru dan renewal dan variabel output pendapatan operasional. Sedangkan untuk variabel input jumlah leads (potential customer) selalu mencapai target dengan tingkat efektivitasi dari tahun ke tahunnya yang mencapai $100 \%$. Pada tahun 2016, persentase efektivitas untuk variabel input akumulasi jumlah pelanggan baru dan renewwal berada di angka $70 \%$, meningkat terus ke tahun-tahun berikutnya dengan pencapaian tingkat efektivitas masing-masing di angka $80 \%$, $90 \%$, dan $100 \%$ (efektivitas maksimal) pada tahun 2019. Peningkatan yang sama juga terjadi untuk variabel output-nya yaitu pendapatan operasional yang sejak tahun 2016-2019 mengalami peningkatan dengan masing-masing persentase setiap tahunnya yaitu $70 \%, 80 \%, 90 \%$, dan $100 \%$.

Dari data di atas dapat dikatakan bahwa penawaran yang masuk dari sisi leads (potential customer) sudah mencapai tingkat efektivitas maksimal setiap tahunnya yaitu di angka $100 \%$. Namun, proses konversi dari leads tersebut menjadi pelanggan (customer) yang masih harus ditingkatkan. Misal, pada tahun 2016, masih ada $30 \%$ target yang belum tercapai dari sisi penambahan jumlah pelanggan baru dan renewal. Meski demikian, jika melihat data secara lebih komprehensif, pengingkatan dari sisi efektivitas sebenarnya sudah terjadi dari tahun ke tahun yang mana peningkatan variabel akumulasi jumlah pelanggan baru dan renewal ini berdampak pula kepada variabel output-nya yaitu pendapatan operasional. Maka, dari data ini dapat disimpulkan bahwa, PT. Jojo Nomic Indonesia memiliki tingkat efektivitas dalam pencarian leads yang maksimal namun masih belum maksimal dalam hal konversi leads menjadi customer. Dapat diartikan juga bahwa efektivitas kinerja penjualan masih perlu peningkatan karena adanya penggunaan input yang kurang efektif. Hal inilah yang kemudian akan coba dijelaskan menggunakan variabel tambahan di luar ekonomi yaitu variabel makna ibadah yang tercermin dalam praktik sholat karyawan sehari-hari.

\section{Implementasi nilai shalat pada efisiensi kinerja:}

A. Intermediasi Nilai Shalat

Dalam penelitian ini kriteria konsep yang digunakan dalam mendefinisikan hubungan keislaman dengan tingkat 
efektivitas pada PT. Jojo Nomic Indonesia adalah waktu dalam pelaksanaan berjamaah shalat, jumlah shaff shalat, dan tempat beribadah (musholla). Dengan pendekatan konsep tersebut dapat mengevaluasi tingkat efektivitas kinerja perusahaan tersebut yang didalamnya sudah memasukan nilai keislaman yang sesuai dengan ajaran islam. Dalam prosedur proses rekayasa dilakukan untuk mengumpulkan data yang dijadikan sampel dalam implementasi teori ini.

Tabel 3. Bobot Penilaian Shalat

\begin{tabular}{|c|c|}
\hline Tahun & Bobot Nilai \\
\hline 2019 & $90 \%$ \\
\hline 2018 & $85 \%$ \\
\hline 2017 & $80 \%$ \\
\hline 2016 & $75 \%$ \\
\hline
\end{tabular}

Sumber: Analis Data, 2020

Berdasarkan data diatas, dilihat dari hasil perhitungan dengan bobot penilaian shalat yang diterapkan pada PT. Jojo Nomic Indonesia. Dari data yang didapat melalui wawancara kepada karyawan di PT. Jojo Nomic Indonesia bahwa mereka telah melaksanakan shalat dengan teratur, tetapi kegiatan shalat secara berjamaah yang umumnya dilakukan oleh para karyawan laki-laki baru aktif di pertengahan 2016 maka dari itu penilaian ditahun 2016 diberikan nilai rata-rata 75\%. Sedangkan ditahun 2017 dan 2018 pengalami peningkatan dari tahun sebelumnya dengan rata-rata masing-masing per tahunnya $80 \%$ dan $85 \%$ dikarenakan pada mulai tahun 2017 kantor PT. Jojo Nomic Indonesia berpindah tempat ke kawasan yang dekat lebih dengan masjid. Jadi, pada tahun ini, selain jamaah sholat berjamaah-nya yang semakin banyak, juga adanya aktivitas shalat berjamaah yang dilakukan di masjid oleh 50\% karyawan laki-laki. Lalu, di tahun 2019 bobot nilai yang diberikan yaitu 90\%, juga mengalami peningkatan dari tahun sebelumnya. Hal ini karena terjadinya peningkatan jumlah karyawan di tahun 2019 ini, dan umumnya karyawan baru yang masuk merupakan seorang muslim yang taat dalam menjalankan ibadah sholatnya sehingga menambah jumlah jamah dan peningkatan ketertiban karyawan dalam melakukan sholat.

Selanjutnya, setelah menilai bobot shalat pada, kemudian dijelaskan dengan nilai Refleksivitas dengan menggunakan rumus: Revleksivitas $=$ Efektivitas $\mathrm{x}$ Shalat $\mathrm{x} 100 \%$
Tabel 4. Nilai Refleksivitas

\begin{tabular}{|c|c|c|c|}
\hline Tahun & Efektivitas & Nilai Sholat & Jumlah \\
\hline 2019 & $100 \%$ & $90 \%$ & $90 \%$ \\
\hline 2018 & $90 \%$ & $85 \%$ & $76,5 \%$ \\
\hline 2017 & $80 \%$ & $80 \%$ & $64 \%$ \\
\hline 2016 & $70 \%$ & $75 \%$ & $52,5 \%$ \\
\hline
\end{tabular}

Sumber: Analis Data, 2020

Dari hasil perhitungan diatas dapat dilihat bahwa nilai reflektivitas selalu terjadi peningkatan dari tahun ke tahun sejak tahun 2016 dan mencapai nilai reflektivitas tertinggi pada tahun 2019 yaitu dengan nilai sebesar 90\%. Sedangkan nilai reflektivitas sejak tahun 20162017 masing-masing yaitu sebesar 52,4\%, 64\%, dan 76,5\%. Pada tahun 2016 bisa kami katakan belum mencapai reflektivitas maksimal dalam ibadah dikarenakan masih sedikitnya jumlah karyawan yang sholat secara berjamaah dan belum adanya aktivitas shalat berjamaah di masjid.

\section{Strategi Penanganan Covid-19}

Perlu dilakukan penyesuaian dalam kondisi Covid-19 sekarang ini dengan hanya terus meratapi kepergian beberapa pelanggan penting atau memikirkan terus menerus bagaimana caranya memaksakan agar proyek tidak perlu ditunda waktu pelaksanaannya. Karena toh, semua terjadi sebagai konsekuensi logis dari adanya pandemi Covid-19 ini dan juga kedua hal itu memang berada di luar kendali PT. Jojo Nomic Indonesia sebagai sebuah perusahaan. Maka yang bisa PT. Jojo Nomic Indonesia lakukan dalam hal ini adalah memanfaatkan apa yang bisa dikendalikan oleh perusahaan seperti sumber daya internal yang, sebagaimana disebutkan di atas, sedang berada dalam tingkat produktivitas yang tinggi. Sumber daya bisa berupa manusia, teknologi, keuangan, atau bahkan ide atau gagasan sekalipun. Semua itu sumber daya yang apabila dapat dimanfaatkan dengan maksimal akan mampu mengembalikan keseimbangan perusahaan kembali di masa krisis ini.

Dari sumber daya manusia, perusahaan bisa memanfaatkan SDM yang sebelumnya sudah di-plot untuk menjalankan proyek tertentu dan ternyata proyek tersebut tertunda pelaksanaannya. Itu artinya, SDM tersebut saat ini sedang dalam masa tunggu (idle) dan bisa dialihkan pemanfaatannya untuk mengerjakan pekerjaan lain yang bisa membawa dampak cepat 
terhadap keseimbangan perusahaan. Begitu juga dari sisi sumber daya teknologi. Sebagai perusahaan yang sedang dalam masa produktif, tentunya eksplorasi teknologi sedang gencargencarnya dilakukan. Maka, hasil eksplorasi itu harus bisa diimplementasikan sesegera mungkin dalam bentuk penciptaan karya di tengah kondisi krisis seperti ini. Lalu, jika sumber dayanya sudah tersedia, maka pertanyaan selanjutnya adalah, apa yang seharusnya diciptakan dari semua sumber daya itu yang dampaknya bisa secara cepat langsung dirasakan oleh perusahaan di tengah kondisi krisis seperti ini? Untuk menjawabnya, kita perlu melihat ke kondisi yang terjadi di lapangan, kemudian rumuskan permasalahan tersebut, cari solusinya dan jadikan solusi itu sebagai sebuah produk teknologi yang dapat diciptakan sesuai dengan spesialisasi PT. Jojo Nomic Indonesia.

\section{Jalur Alternatif}

Di antara alternatifnya perumusan masalahnya bisa seperti ini:

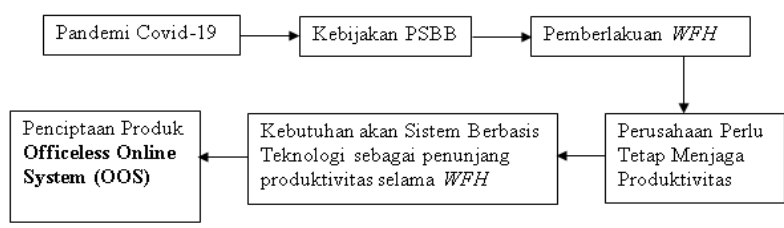

Dari alur perumusan masalah di atas, dapat disimpulkan bahwa salah satu strategi penting yang dapat dilakukan oleh PT. Jojo Nomic Indonesia dalam menghadapi dampak ekonomi akibat pandemi Covid-19 ini adalah menciptakan Oficeless Online System (OOS). OOS dapat diartikan sebagai sebuah sistem penunjang berbasis teknologi yang dapat diakses oleh karyawan kapan saja dan di mana saja secara online yang berguna untuk menjaga produktivitas selama bekerja di rumah. Selain itu, sistem ini juga bisa digunakan untuk melakukan monitoring dan kerja sama (collabs working) dengan anggota tim lainnya secara langsung sehingga tidak ada lagi hambatan karena jarak untuk bekerja secara tim.

\section{KESIMPULAN}

Berdasarakan Berdasarkan perhitungan efektivitas kinerja di PT. Jojo Nomic Indonesia pada tahun 2019 mengalami tingkat efektivitas yang maksimal $100 \%$ dilihat dari sisi efektivitasi variabel outputnya yaitu pendapatan operasional.
Sedangkan pada tahun-tahun sebelumnya periode tahun 2016-2018 belum mencapai tingkat efektivitasi maksimal $100 \%$ tetapi tren peningkatannya selalu positif dari tahun ke tahunnya. Jika melihat dari sisi variabel input yaitu akumulasi jumlah pelanggan baru dan renewal dan jumlah leads (potential customer), maka dapat terlihat bahwa sebenarnya perusahaan sudah efektif dalam pencapaian target leads namun tidak demikian dengan target jumlah pelanggan baru dan renewal atau dengan kata lain konversi yang dilakukan dari leads tersebut menjadi pelanggan (customer) masih kurang efektif dilakukan. Namun demikian, tren peningkatannya juga selalu naik dari tahun ke tahun dalam hal peng-konversian leads menjadi pelanggan. Fakta ini menggambarkan bahwa adanya peningkatan efektivitas kinerja dari seluruh sumber daya manusia di PT. Jojo Nomic Indonesia sejak tahun 2016-2019 dalam banyak hal dari seluruh divisi yang ada. Misal, dari divisi produk berjuang untuk memperbaiki produknya menjadi seunggul mungkin sehingga banyak diminati oleh pelanggan dan bisa bersaing dengan kompetitor. Kemudian, dari divisi sales (penjualan) juga berusaha keras untuk bisa menjual produk dengan baik sehingga meningkatkan conversion rate (tingkat konversi dari leads menjadi customer). Begitu juga dengan seluruh karyawan di divisi-divisi lain, mereka pun berjuang untuk meningkatkan efektivitas kinerja di bidang mereka masing-masing.

Jika melihat pada bobot nilai ibadah, yang dalam hal ini ibadah sholat, maka dapat disimpulkan bahwa peningkatan efektivitas kinerja karyawan sejalan dengan peningkatan yang terjadi pada bobot nilai dalam ibadahnya. Hal ini tercermin dari nilai refleksivitas ibadah dalam kinerja karyawan yang sejak tahun 20162019 selalu meningkat angkanya. Puncaknya terjadi pada tahun 2019, di mana efektivitas kinerja yang dilihat dari variabel output (pendapatan operasional) mencapai titik maksimal $100 \%$ sejalan dengan adanya peningkatan yang juga cukup signifikan dalam bobot nilai ibadah karyawan menjadi $90 \%$ sehingga dapat dihitung nilai refleksivitasnya berada di persentase $90 \%$. Dengan kata lain, nilai ibadah sholat cenderung berpengaruh besar terhadap peningkatan efektivitas kinerja karyawan di PT. Jojo Nomic Indonesia.

Penciptaan produk OOS bisa dijadikan sebagai jawaban atas kebutuhan perusahaanperusahaan yang memberlakukan wfh selama 
masa pandemi ini dan juga untuk perusahaan yang memang secara permanen melaksanakan mekanisme wfh. Artinya, dari segi permintaan terhadap produk OOS ini sudah ada, tinggal bagaimana PT. Jojo Nomic Indonesia sebagai sebuah startup berbasis teknologi B2B mampu menjawab tantangan permintaan tersebut dengan proses penciptaan produk OOS ini. Terlebih lagi, bagi PT. Jojo Nomic Indonesia sendiri, penciptaan OOS ini dapat menjadi langkah konkret untuk menjaga keseimbangan perusahaan di tengah krisis yang diciptakan sebagai dampak pandemi Covid-19.

\section{DAFTAR PUSTAKA}

Al-Quran Surat Adz-Dzariyat [51]: 56

Al-Quran Surat Al-Baqarah [2]: 275

Aziz, Mochamad Roikhan, Acep R. Jayaprawira, Sulistyowati. 2019. Determinant of Islamic Pension Fund In Indonesia. International Journal of Islamic Business and Economics 2599-3216: 51-59.

Aziz, Mochamad Roikhan. 2012. New Paradigm on Islamic Kaffah in Islamic Economics. Jurnal Signifikan, Vol 1 No 2.

Aziz, Mochamad Roikhan. 2015. "Teori H dalam Islam sebagai Wahyu dan Turats". Jurnal UIN Syarif Hidayatullah.

Bahari, Zakaria. 2014. Metodologi Penelitian Ekonomi Islam. Makalah Konferensi Internasional Pembangunan Islami -I: 6388

Ismail, Abdul Ghafar, Bayu Taufiq. 2012. The Philosophical Determinants of Economic in Islam; Bringing Economic and Religion Together. Working Paper in Islamic Economics and Finance No. 1211

Ismail, Abdul Ghafar. 2008. Evolution of Islamic Economic Views. Working Paper in Islamic Economics and Finance No. 0906

Muiz, Abang Mohd, et al. 2018. Islamic Perspective on Human Development Management: A Philosophical Approach. International Journal of Academic Research in Business and Social Sciences Vol. 8: 543-552.

Musari, Khairunnisa, Rusli Simanjuntak. 2015. Conceptual Framework On The Methodology Of Islamic Economics: An Alternative Approach Based On Existing Models. The 2nd International Conference On Islamic Development.
Rosdi, Mohd Syakir. 2016. Ummah Economic Remedy: Between Islamic Economics and Islamic Political Economy. Journal Of Business Management And Economics Vol. 4: 38-46

Soenjoto, Wening Purbatin. 2017. Mengkaji Krisis Ekonomi Global Menurut Perspektif Islam. Tafaqquh: Jurnal Penelitian dan Kajian Keislaman Volume 5, Nomor 1: 3454.

Tahir, Sayyid. 2014. Islamic Perspectives on Economic Development. Pakistan Development Review Vol. 34: 845-856. 